\title{
OPTIMASI WAKTU REAKSI DAN VOLUME PELARUT PADA PEMBUATAN SUKROSA ESTER DARI METIL ESRTER
}

\section{OPTIMIZATION OF REACTION TIME AND SOLUTION VOLUME ON THE MAKING OF SUCROSE ESTER FROM METHYL ESTER}

\author{
Sukmawati, Pratiwi Putri Lestari* \\ Institut Teknologi Medan \\ *Corresponding author: pratiwiputri@itm.ac.id
}

\begin{abstract}
ABSTRAK
Sukrosa ester merupakan salah satu jenis surfaktan yang dihasilkan dengan cara disintesis dari minyak nabati, dimana pada sebelumnya surfaktan disintesis dari minyak bumi yang semakin lama semakin menurun produksinya serta sukar terurai secara biologi. Surfaktan mempunyai sifat-sifat sebagai pengemulsi, pembusaan, deterjen dan pelarutan. Tujuan penelitian ini yaitu untuk menentukan waktu reaksi/pengoperasian dan volume pelarut yang optimum pada pembuatan sukrosa ester dan menghitung bilangan penyabunan, bilangan asam dan nilai HLB pada pembuatan sukrosa ester dari metil ester. Bahan yang digunakan dalam penelitian ini adalah metil ester, sukrosa, dan air. Alat yang digunakan pada penelitian ini adalah labu leher tiga, termometer, magnetik stirer, pendingin liebig, beaker glass, erlenmeyeer, buret, gelas ukur, penangas air dan corong pemisah. Metode yang digunakan pada penelitian ini yaitu metode esterifikasi. Dari hasil penelitian dengan waktu pengoperasian yaitu 3, 4, 5, 6 dan 7 jam serta variasi volume pelarut 80, 85 , dan $90 \mathrm{ml}$ diperoleh nilai optimum produk sukrosa ester yaitu pada waktu 3 jam dengan volume pelarut $80 \mathrm{ml}$. Hasil analisa produk yang diperoleh yaitu konsentrasi sukrosa ester sebesar 3,225 mol/liter, nilai bilangan penyabunan 9,35, nilai bilangan asam 70,125, dan bilangan HLB sebesar 17,333 yang menunjukkan bahwa surfaktan yang dihasilkan termasuk jenis pengemulsi o/w (pengemulsi minyak dalam air).
\end{abstract}

Kata kunci : Sukrosa; Metil Ester; Surfaktan.

\begin{abstract}
ABSTRAK
Sucrose estersare one type of surfactant that is produced by synthesizing petroleum which decreases its production and decreases biologically. Surfactans have properties as emulsifiers, foaming, detergent and dissolution.The purpose of this study is to determine the reaction time or operation and the optimal volume of solvent in the manufacture of sucrose esters and calculate saponification numbers, acid numbers, and HLB value in the manufacture of sucrose esters from methyl esters. Materials used in this study is the methyl ester, sucrose, and water. The tools used in this study is a three-neck flask, thermometer, magnetic stirrer, cooling liebig, beaker glass, erlenmeyeer, buret, measuring cup, water bath, reflux flask, funnel separator. The method used in this study is the esterification method. From the research results with operating time is 3, 4, 5, 6 and 7 hours with and solvent volume variation 80, 85, dan $90 \mathrm{ml}$ obtained the optimum value of sucrose product ester that is a 3 hours with a solvebt volume of $80 \mathrm{ml}$. The analysis result are the sucrose ester concentration 3,225 mol/liter, 9,35 saponification numbers, 70,125 acid numbers, and 17,333 HLB value which shows that the surfactant produced is a type of o/w )oil-in-water emulsifier).
\end{abstract}

Keywords : Sucrose; Methyl Ester; Surfactan. 


\section{PENDAHULUAN}

Dewasa ini kepedulian masyarakat akan ekosistem dan lingkungan semakin meningkat, sehingga ketertarikan dalam memodifikasi dan membuat produk baru menjadi cenderung berupa produk yang bersifat biodegradable atau ramah lingkungan dan berasal dari sumber daya alam terbarukan. Sejalan dengan meningkatnya kebutuhan akan produk-produk seperti industri makanan, farmasi, kosmetik, deterjen, cat dan plastik yang semakin meningkat dengan pesatnya, maka kebutuhan akan bahan aditif seperti surfaktan juga akan meningkat. Oleh karena itu perlu dilakukan penelitian lebih lanjut terhadap surfaktan untuk dapat memenuhi kebutuhan dunia industri tersebut.

Surfaktan umumnya disintesis dari minyak bumi (petrokimia). Saat sekarang ini produksi minyak bumi semakin menurun dan sifat surfaktan yang sukar terurai secara biologi, masih ada sumber alam lain yang dapat digunakan sebagai bahan baku surfaktan yaitu minyak nabati. Minyak kelapa sawit seperti umumnya. Minyak nabati merupakan senyawa yang tidak dapat larut didalam air yang mempunyai potensi sebagai bahan baku surfaktan, karena minyak sawit tersusun dari unsur-unsur karbon, hidrogen, dan oksigen $(\mathrm{C}, \mathrm{H}$, dan $\mathrm{O})$ yang mengandunng sekitar $42 \%$ asam palmitat dan asam oleat sekitar $38 \%$. Keunggulan yang dimiliki oleh minyak nabati dibandingkan dengan minyak bumi yaitu surfaktan yang dihasilkan dari bahan baku minyak nabati pada umumnya mudah terurai secara biologi sehingga cenderung tidak mencemari lingkungan dan tidak perlu dikhawatirkan kesinambungan pengadaannya karena minyak nabati merupakan sumber daya alam yang dapat diperbaharui.

Surfaktan banyak ditemui dibahan seperti deterjen, kosmetik, farmasi serta tekstil. Adapun beberapa syarat yang harus dipenuhi oleh surfaktan sebagai berikut.

- Mempunyai nilai HLB (Hydrophile lipophile Balance) antara 2-16

- Bila nilai HLB tinggi(>16) dapat berlaku sebagai pelarut

- Tidak beracun dan tidak menimbulkan iritasi

Sintesis sukrosa ester dilakukan dengan cara esterifikasi ester minyak nabati atau asam lemak dengan sukrosa menggunakan atau tanpa pelarut pada kondisi operasi tertentu. Umumnya bahan baku yang digunakan adalah asam linoleat murni, asam stearat murni, dan asam oleat murni. Namun penelitian mengenai sintesa sukrosa ester dari minyak sawit atau asam lemak sawit belum banyak dipublikasikan, hal ini mungkin dikarenakan sebagian besar penelitian mengenai sintesis bahan surfaktan ini dilakukan dinegara-negara Amerika dan Eropa yang diproduksi soybean oil-nya cukup melimpah.

Hasil penelitian sebelumnya yang telah dilakukan oleh Suwindi dan M.Iqbal Maulana pada Pembuatan Sukrosa Ester dari Metil Ester Minyak Sawit diperoleh nilai HLB sebesar 6,8-17,4, dimana konsentrasi sukrosa ester bertambah dengan bertambahnya waktu reaksi pada variasi waktu 4, 6 dan 8 jam serta temperatur $135^{\circ} \mathrm{C}$. Semakin besar perbandingan berat bahan baku yang divariasikan dan pertambahan waktu, maka bilangan penyabunan dan bilangan asam akan semakin kecil. Nilai HLB ini menunjukkan jenis surfaktan yang digunakan sebagai pengemulsi w/o (pengemulsi air didalam minyak). Sifat-sifat diatas memungkinkan sukrosa ester untuk digunakan sebagai surfaktan dalam industri farmasi, deterjen, dan kosmetik. Sukrosa ester juga dapat digunakan sebagai elmusifier dalam industri makanan karena memiliki sifat yang tidak beracun, tidak berasa serta didalam lambung mudah terurai menjadi sukrosa dan asam emak.

Penelitian yang dilakukan saat ini, melanjutkan dari penelitian yang telah dilakukan sebelumnya, tetapi juga dalam kondisi yang berbeda dimana menggunakan variasi waktu reaksi 3 jam, 4 jam, 5 jam, 6 jam dan 7 jam dengan temperatur operasi $110^{\circ} \mathrm{C}$. 


\section{METODE PENELITIAN}

\subsection{Bahan dan Alat}

Variabel dan Kondisi Proses

- Variabel Tetap Proses:

- Metil ester dan Sukrosa

- Larutan KOH, N-Heksan, Benzen, $\mathrm{NaOH}$ dan $\mathrm{Na}_{2} \mathrm{CO}_{3}$

- Pelarut Air

- Rasio Metil Ester : Sukrosa = 6:7

- Temperatur $110^{\circ} \mathrm{C}$
- Variabel Tidak Tetap

- Waktu reaksi $=3,4,5,6$, dan 7 jam

- Volume Pelarut air = 80, 85 dan $90 \mathrm{ml}$

- Analisa yang dilakukan terhadap sukrosa ester yang dihasilkan :

- Menghitung bilangan penyabunan, bilangan asam, dan nilai HLB

\subsection{Metode Interesterifikasi (Pembuatan Sukrosa Ester Asam Lemak)}

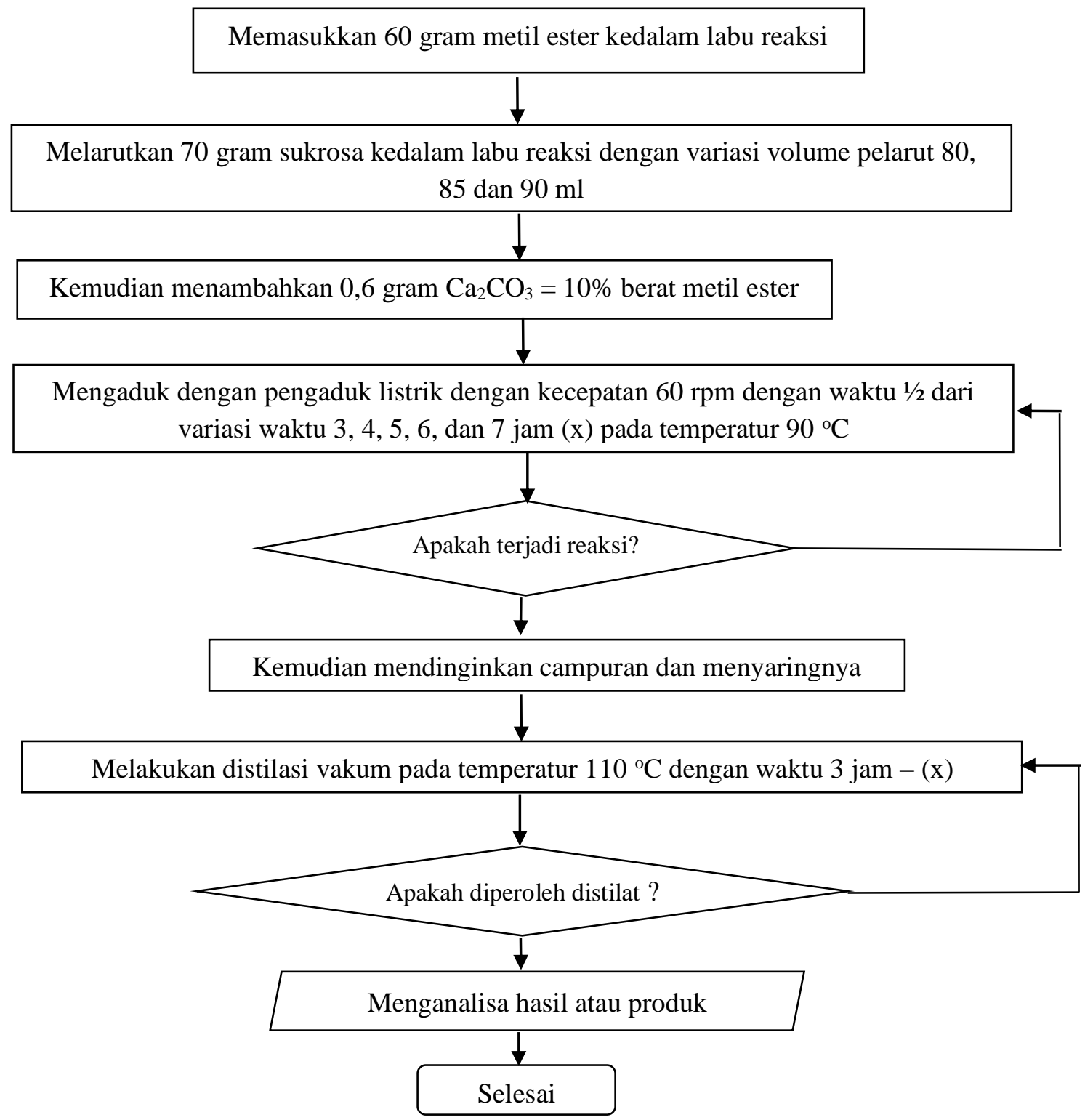

Gambar 1. Proses Pembuatan Sukrosa Ester Asam Lemak 


\section{HASIL DAN PEMBAHASAN}

\subsection{Hasil Penelitian}

Kondisi operasi yaitu kecepatan pengadukan $60 \mathrm{rpm}$ dengan variasi perbandingan waktu reaksi dan volume pelarut pada temperatur $110^{\circ} \mathrm{C}$. Hasil percobaan disajikan pada tabel-tabel berikut :

Tabel 1. Konsentrasi Sukrosa Ester (Cc) setiap waktu

\begin{tabular}{cccc}
\hline $\begin{array}{c}\text { Variasi waktu } \\
\text { reaksi (jam) }\end{array}$ & $\mathbf{8 0}$ ml pelarut & $\mathbf{8 5}$ ml pelarut & $\mathbf{9 0}$ ml pelarut \\
\cline { 2 - 4 } & 3,225 & 2,894 & 2,733 \\
\hline 3 & 2,689 & 3,035 & 2,676 \\
\hline 4 & 2,365 & 2,936 & 2,102 \\
\hline 5 & 2,967 & 2,792 & 2,637 \\
\hline 6 & 2,365 & 2,894 & 2,389 \\
\hline 7 & &
\end{tabular}

Tabel 2. Hasil Analisa Sukrosa Ester

\begin{tabular}{|c|c|c|c|c|c|c|c|c|c|}
\hline \multirow{2}{*}{$\begin{array}{c}\text { Variasi } \\
\text { waktu } \\
\text { reaksi } \\
\text { (jam) }\end{array}$} & \multicolumn{3}{|c|}{ Bilangan penyabunan } & \multicolumn{3}{|c|}{ Bilangan asam } & \multicolumn{3}{|c|}{ Nilai HLB } \\
\hline & $\begin{array}{c}80 \mathrm{ml} \\
\text { pelarut }\end{array}$ & $\begin{array}{c}85 \mathrm{ml} \\
\text { pelarut }\end{array}$ & $\begin{array}{c}90 \mathrm{ml} \\
\text { pelarut }\end{array}$ & $\begin{array}{c}80 \mathrm{ml} \\
\text { pelarut }\end{array}$ & $\begin{array}{c}85 \mathrm{ml} \\
\text { pelarut }\end{array}$ & $\begin{array}{c}90 \mathrm{ml} \\
\text { pelarut }\end{array}$ & $\begin{array}{c}80 \mathrm{ml} \\
\text { pelarut }\end{array}$ & $\begin{array}{c}85 \mathrm{ml} \\
\text { pelarut }\end{array}$ & $\begin{array}{c}90 \mathrm{ml} \\
\text { pelarut }\end{array}$ \\
\hline 3 & 9,35 & 13,09 & 13,09 & 60,775 & 89,76 & 60,775 & 17,333 & 17,083 & 15,692 \\
\hline 4 & 18,7 & 9,35 & 15,895 & 117,81 & 78,54 & 117,81 & 17,333 & 17,619 & 17,3 \\
\hline 5 & 19,635 & 11,22 & 19,635 & 140,25 & 70,125 & 140,025 & 14,4 & 16,8 & 17,2 \\
\hline 6 & 14,025 & 14,025 & 14,025 & 92,164 & 67,32 & 92,164 & 17,333 & 15,833 & 16,95 \\
\hline 7 & 19,635 & 18,7 & 13,09 & 70,125 & 72,128 & 70,125 & 17,9 & 14,814 & 16,26 \\
\hline
\end{tabular}

\subsection{Pembahasan}

\subsubsection{Pembahasan Konsentrasi Sukrosa Ester Setiap Waktu}

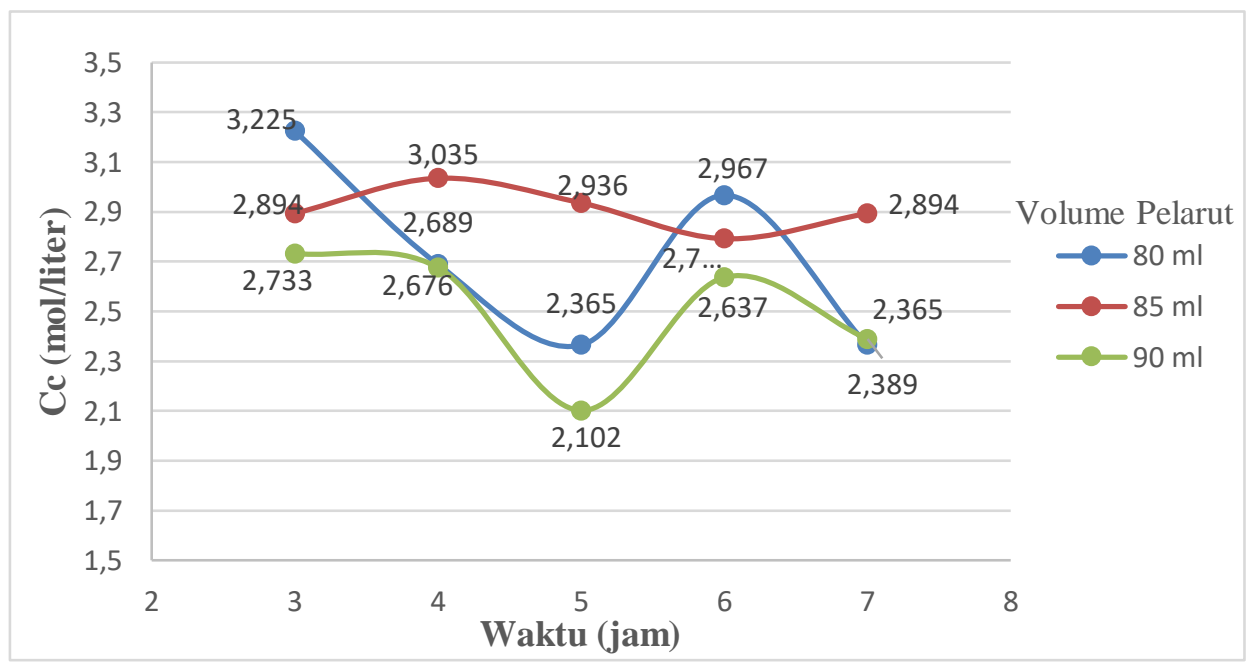

Gambar 2. Hubungan Konsentrasi Sukrosa Ester vs Waktu 
Berdasarkan grafik diatas, dapat dilihat bahwa pada volume pelarut $80 \mathrm{ml}$ grafik mengalami penurunan dan kenaikan konsentrasi sukrosa ester. Grafik mengalami penurunan pada waktu 5 jam dengan konsentrasi 2,365 mol/liter dan mengalami kenaikan pada waktu 6 jam dengan konsentrasi 2,967 mol/liter kemudian mengalami penurunan kembali pada waktu 7 jam dengan konsentrasi 2,365 $\mathrm{mol} / \mathrm{liter}$.

Pada volume pelarut $85 \mathrm{ml}$, grafik juga mengalami penurunan dan kenaikan konsentrasi sukrosa ester dengan konsentrasi yang tinggi di tujukkan pada waktu 4 jam dengan nilai konsentrasi sukrosa ester 3,035 mol/liter dan mengalami penurunan pada waktu 6 jam dengan konsentrasi 2,792 $\mathrm{mol} /$ liter kemudian mengalami kenaikan kembali pada waktu 7 jam dengan konsentrasi 2,894 $\mathrm{mol} / \mathrm{liter}$.

Pada volume pelarut $90 \mathrm{ml}$ grafik juga mengalami penurunan dan kenaikan konsentrasi ester. Grafik mengalami penurunan pada waktu 5 jam dengan konsentrasi 2,102 mol/liter ini merupakan konsentrasi sukrosa ester yang terendah, kemudian mengalami kenaikan pada waktu 6 jam dengan konsentrasi 2,637 mol/liter dan mengalami penurunan kembali pada waktu 7 jam dengan konsentrasi 2,389 $\mathrm{mol} / \mathrm{liter}$.

Penurunan konsentrasi sukrosa ester disebabkan oleh pelarut air yang tidak menguap seluruhnya, sehingga mengurangi konsentrasi sukrosa ester. Dan kenaikan konsentrasi sukrosa ester disebabkan oleh pelarut air yang menguap lebih banyak. Hasil yang diperoleh tidak sesuai dengan teori yang menyatakan bahwa semakin lama waktu yang digunakan maka semakin banyak pelarut air yang teruapkan akan semakin besar konsentrasi dari sukrosa esteryang dihasilkan.

Semua rasio diatas setiap jenis pengemulsi memiliki volume pelarut yang berbeda dalam menghasilkan system emulsi.

Pengemulsi sukrosa ester asam lemak cenderung stabil pada variasi volume pelarut $80 \mathrm{ml}$ dengan waktu pengoperasian selama 3 jam. Sukrosa ester asam lemak yang dihasilkan merupakan pengemulsi yang lebih bersifat hidrofilik sehingga lebih cocok untuk jenis emulsi minyak dalam air $(\mathrm{o} / \mathrm{w})$.

\subsubsection{Bilangan Penyabunan}

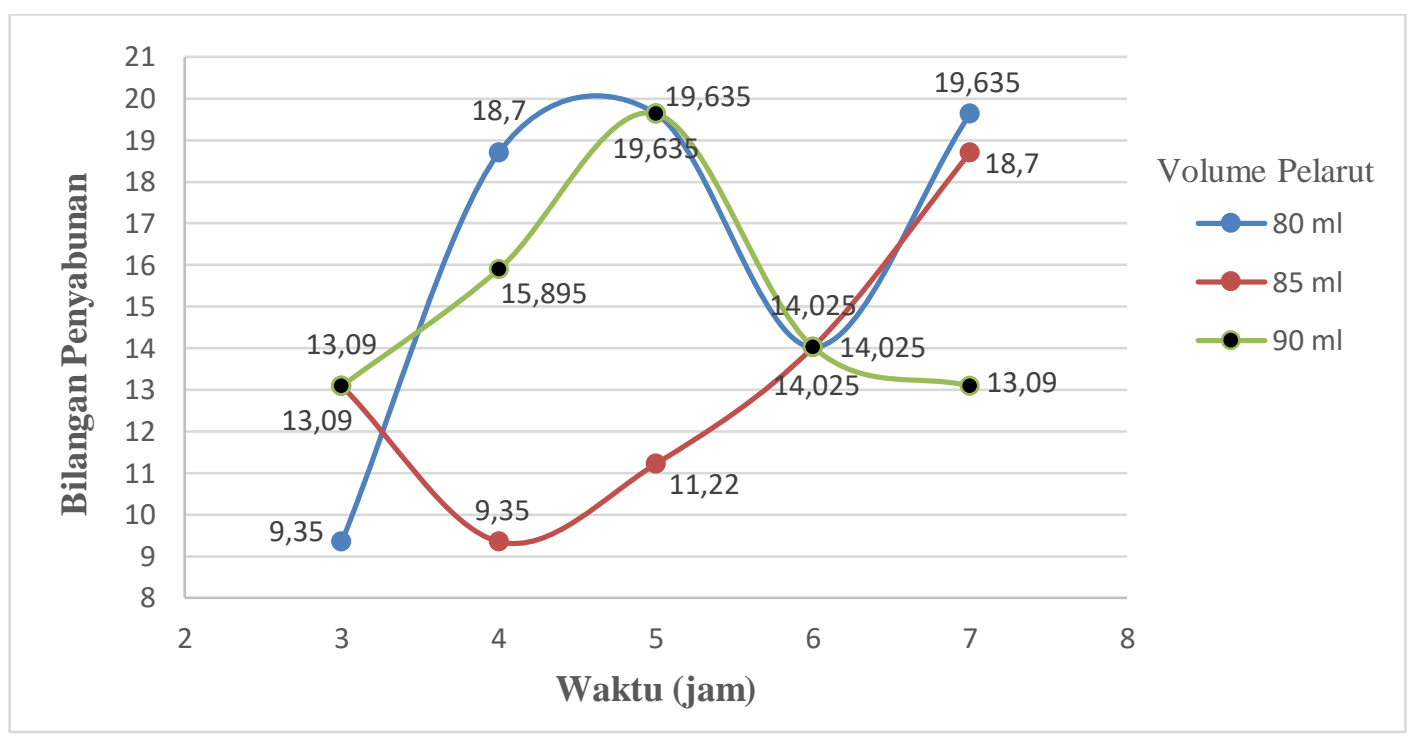

Gambar 3. Grafik Hubungan Bilangan Penyabunan vs Waktu

Grafik diatas dapat dilihat bahwa pada volume pelarut $80 \mathrm{ml}$ grafik mengalami kenaikan dan penurunan bilangan penyabunan. Grafik mengalami kenaikan pada waktu 5 jam dengan nilai bilangan penyabunan 19,635 dan mengalami penurunan pada waktu 6 jam dengan nilai bilangan 
penyabunan 14,025 kemudian mengalami kenaikan kembali pada waktu 7 jam dengan nilai bilangan penyabunan 19,635 .

Pada volume pelarut $85 \mathrm{ml}$ grafik mengalami kenaikan dan penurunan bilangan penyabunan. Grafik mengalami penurunan pada waktu 4 jam dengan nilai bilangan penyabunan 9,35 dan mengalami kenaikan pada waktu 7 jam dengan nilai bilangan penyabunan 18,7.

Pada volume pelarut $90 \mathrm{ml}$ grafik juga mengalami kenaikan dan penurunan bilangan penyabunan.Grafik mengalami kenaikan pada waktu 5 jam dengan nilai bilangan penyabunan 19,635 dan mengalami penurunan pada waktu 7 jam dengan nilai bilangan penyabunan 13,09.

Penurunan bilangan penyabunan disebabkan oleh jumlah sukrosa ester yang terbentuk semakin besar, hal ini sesuai dengan teori yang menyatakan semakin besar jumlah sukrosa ester yang terbentuk maka bilangan penyabunan yang dihasilkan semakin kecil, karena sukrosa yang terbentuk mengandung asam lemak dengan rantai $\mathrm{C}$ yang lebih panjang sehingga akan diperoleh bilangan penyabunan yang semakin kecil. Sebaliknya, kenaikan bilangan penyabunan disebabkan oleh jumlah sukrosa ester yang terbentuk lebih kecil. Hal itu dikarenakan bahwa pelarut yang terdapat didalam sukrosa ester belum menguap sepenuhnya, sehingga masih terdapat pelarut didalam sukrosa ester.

\subsubsection{Bilangan Asam}

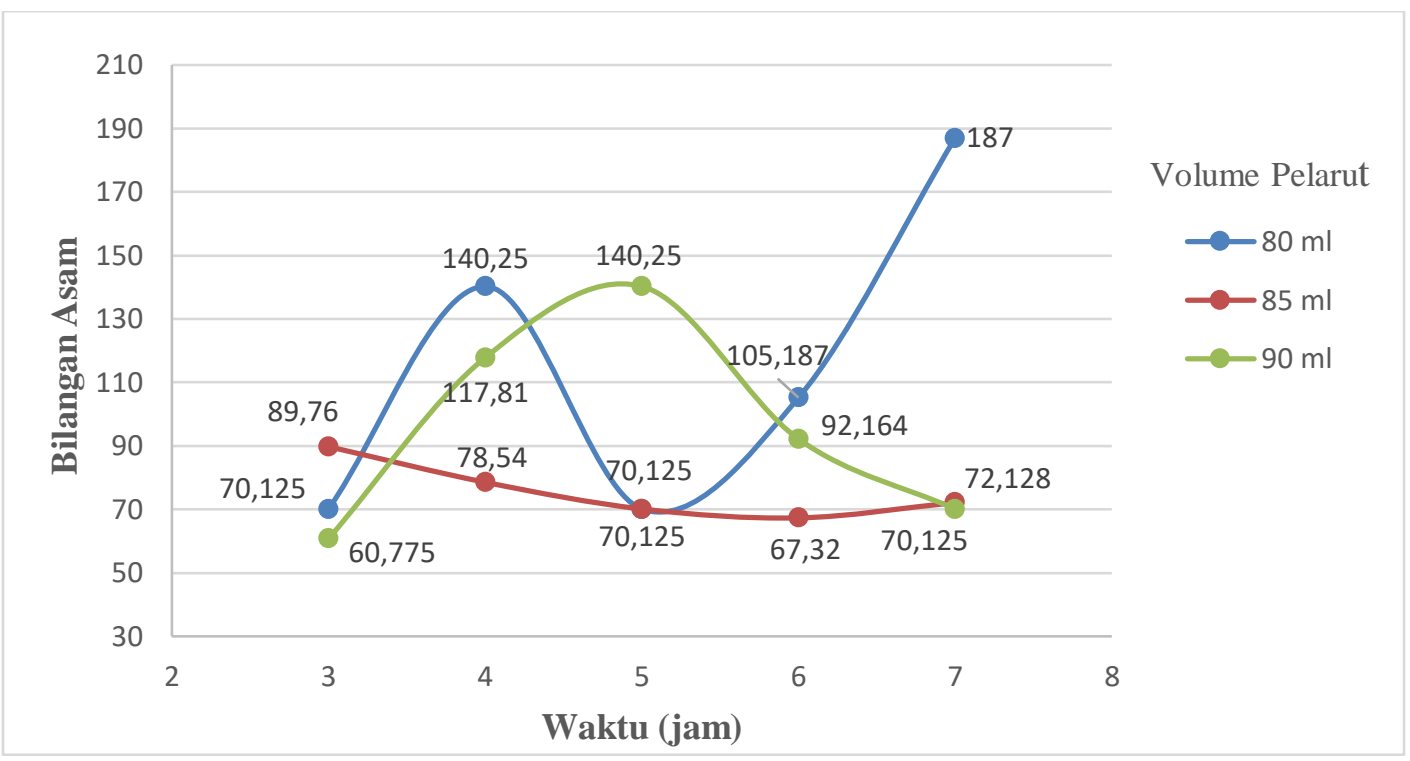

Gambar 4. Grafik Hubungan Bilangan Asam vs Waktu

Dari grafik diatas dapat dilihat bahwa pada volume pelarut $80 \mathrm{ml}$ grafik mengalami kenaikan dan penurunan bilangan asam. Grafik mengalami kenaikan pada waktu 4 jam dengan nilai bilangan asam 140,25 dan mengalami penurunan pada waktu 5 jam dengan nilai bilangan asam 70,125 kemudian mengalami kenaikan kembali pada waktu 7 jam dengan nilai bilangan asam 187 .

Pada volume pelarut $85 \mathrm{ml}$ grafik mengalami kenaikan dan penurunan bilangan asam. Grafik mengalami penurunan pada waktu 6 jam dengan nilai bilangan asam 67,32 Dan mengalami kenaikan pada waktu 7 jam dengan nilai bilangan asam 72,128.

Pada volume pelarut $90 \mathrm{ml}$ grafik mengalami kenaikan dan penurunan bilangan asam. Grafik mengalami kenaikan pada waktu 5 jam dengan nilai bilangan asam 140,25 dan mengalami penurunan pada waktu 7 jam dengan nilai bilangan asam72,128.

Penentuan bilangan asam dipergunakan untuk mengukur jumlah asam lemak bebas yang terdapat dalam minyak atau lemak. Besarnya bilangan asam tergantung dari kemurnian dan umur dari minyak atau lemak tersebut. 
Penurunan bilangan asam disebabkan jumlah sukrosa ester yang terbentuk semakin besar. Hal ini menunjukkan asam lemak bebas yang terbentuk lebih kecil, semakin kecil bilangan asam maka semakin tinggi kualitas sukrosa ester. Dan kenaikan bilangan asam disebabkan jumlah sukrosa ester yang terbentuk semakin kecil, hal ini dikarenakan pada waktu tertentu sukrosa ester yang dihasilkan masih mengandung pelarut air yang belum sepenuhnya menguap saat pengoperasian berlangsung.

Bilangan asam yang besar menunjukkan asam lemak bebas yang besar pula, yang berasal dari hidrolisa minyak atau lemak.

\subsubsection{Nilai HLB}

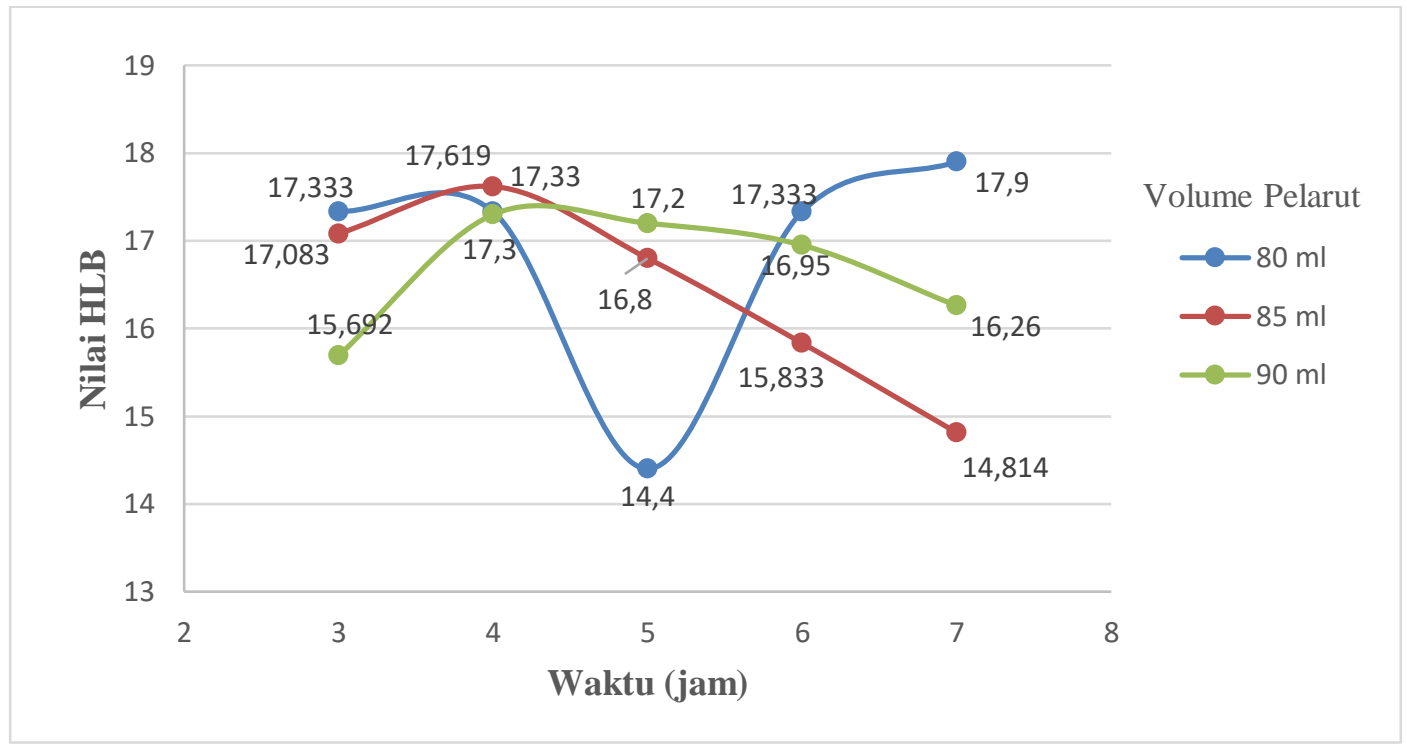

Gambar 5. Grafik Nilai HLB vs Waktu

HLB dapat menentukan bila suatu surfaktan sebagai bahan pengemulsi, deterjen, ataupun bahan pelarut. Berdasarkan hasil pengamatan yang telah diperoleh nilai HLB pada range 14,4 17,9 pada variasi waktu3 jam, 4 jam, 5 jam, 6 jam dan 7 jam. Dari tabel 3.1 mengenai penentuan jenis surfakatan berdasarkan nilai HLB nya dapat dinyatakan bahwa surfaktan yang dihasilkan termasuk jenis pengemulsi o/w (pengemulsi minyak dalam air).

Dimana hal ini sesuai dengan teori karakteristik dari surfaktan emulsifier dapat diklasifikasikan berdasarkan nilai HLB. HLB dapat memprediksi sifat dan informasi yang cukup berkaitan dengan aplikasi surfaktan. HLB yang rendah menunjukkan lipofilitas yang tinggi dan HLB yang tinggi menunjukkan hidrofilitas yang tinggi.

Berdasarkan klasifikaasi HLB tersebut, maka nilai HLB yang rendah dan jenis emulsi yang terbentuk berupa air dalam minyak (w/o), sedangkan sukrosa ester dengan nilai HLB yang tinggi dan jenis emulsi yang terbentuk berupa minyak dalam air $(\mathrm{o} / \mathrm{w})$.

\subsubsection{Nilai Optimum pada Metil Ester dan Sukrosa pada Produk Sukrosa Ester}

Pada Pembuatan Sukrosa Ester akan diperoleh konsentrasi yang besar jika jumlah pelarut air semakin sedikit, dengan demikian nilai bilangan penyabunan akan semakin kecil dan nilai bilangan asam juga akan semakin kecil, dimana semakin kecil bilangan asam maka akan semakin tinggi tinggi kualitas sukrosa ester. 
Pada penelitian ini Pembuatan Sukrosa Ester didapat nilai yang optimum yaitu pada waktu 3 jam dengan volume pelarut $80 \mathrm{ml}$. Didapatkan konsentrasi sebesar 3,225 mol/liter, nilai bilangan penyabunan 9,35, dan nilai bilangan asam 70,125. Dengan nilai HLB 17,333 yang tinggi dan jenis emulsi yang terbentuk berupa minyak dalam air $(\mathrm{o} / \mathrm{w})$.

\section{KESIMPULAN}

Dari penelitian ini dapat disimpulkan bahwa:

1. Produk sukrosa ester dapat digunakan sebagai pengemulsi deterjen.

2. Sukrosa ester pada penelitian ini termasuk pengemulsi hidrofilik sehingga lebih cocok untuk emulsi jenis minyak dalam air $(\mathrm{o} / \mathrm{w})$

3. Sukrosa Ester yang dihasilkan memliliki kondisi optimum pada waktu 3 jam dengan volume pelarut $80 \mathrm{ml}$, dengan karakteristik sebagai berikut :

- Konsentrasi : 3,225 mol/liter

- Nilai bilangan penyabunan $\quad: 9,35$

- Nilai bilangan asam

$: 70,125$

- Nilai HLB

$: 17,333$

- Jenis emulsi

: minyak dalam air $(\mathrm{o} / \mathrm{w})$.

\section{DAFTAR PUSTAKA}

Adamapoulos,.2010. “Studi Awal Mengenai Pembuatan Surfaktan Dari Ampas Tebu”. Jurusan Teknik Kimia. Yogyakarta:UNDIP.

Anonim, 2012.Luas Lahan Sawit Indonesia 9,27 Hektar.

Biscaia F.C, Joana, 2008. Kayu: Kimia, ultra struktur dan reaksi-reaksi. Terjemahan olehHardjono Sastrohamidjojo. Yogyakarta: GadjahMada University Press.

Hysis, 2011. Development of water reducing agent from creosote oil. J. Conc. Sci, 63(2), 111-123.

Suwindi \& Iqbal, 2017. "Optimasi rasio perbandingan metil ester : sukrosa dengan waktu pada pembuatan sukrosa ester dari metil ester". Jurusan Teknik Kimia, Institut Teknologi Medan, Sumatera Utara.

Whitehurst,2004. Ammoxidizedlignosulfonate cementdispersant. US-Patent: US 6,238,475 B1.https://id.wikipedia.org/wiki/Surfaktan. 